\title{
Outdoors in Preschool Teaching: A Model Implementation in Turkey
}

\author{
Dondu Neslihan Bay \\ Eskişehir Osmangazi University \\ Turkey
}

Received: Nov. 30, 2015 Accepted: Jan.11, 2015 Published: February 1, 2016

doi:10.5296/jse.v6i1.8806

URL: http://dx.doi.org/10.5296/jse.v6i1.8806

\begin{abstract}
In the research, an explanatory case study was carried out which is a kind of qualitative research. By presenting a model implementation, how to create outdoor centers and teachers' views on the designed model are introduced with the purpose of making a contribution to teachers and preschool education institutions. Within this framework, by receiving opinions of teachers, an outdoor space design was made, and by the end of a 2 month work, 12 centers (art, music, playing house, writing, balance, eye-hand coordination, vegetable, fruit, book, performance, sensory) were created in the garden of research and application kindergarten of a university. After 6 teachers used the design in the 2 month education period, their opinions are received. Teachers expressed the efficiency of center designs in the garden in terms of supporting children's development and implementing educational programs. Model implementation was described in detail and was discussed with the related body of literature. A design was made regarding how center implementation which will support children development in the best way can be formed using low-cost waste and natural material. The model is thought to raise awareness about putting outdoor space in good use.
\end{abstract}

Keywords: Preschool, outdoor, center, garden. 


\section{Introduction}

Learning by discovery, development of creativity and game-based learning which are the basic characteristics of preschool education program are possible with the necessary arrangement of outdoor space (Yazıc1, Yellice, \&Özer, 2003). Children can be freer and can use all of their senses actively experiencing the nature. In this time spent actively, children are in accordance with peers and gain life skills cooperatively. (Çukur, 2011; Richardson, 2006). Outdoor space is quite a learning environment and supports children's development in many areas such as discovery, self-esteem, creativity, coordination, space perception, questioning (Başbay, 2012). In other words, a well-designed physical environment helps children develop their motor, cognitive, language, social development, learning, making decision and aesthetics skills (Çukur, 2011; Yazıc1, Yellice, \&Özer, 2003). Therefore, to support children's zone of development, outdoor spaces should be organized along with in-school and in-class spaces (Jalongo\& Isenberg, 2000; Acer, 2007).

Outdoor activities support physical development as children can do bodily movements more flexible, moreover, these activities support children's social interactions as they make up their own games together (Henniger, 1999). To provide children with desired developmental contributions, in alliance with the inner design, different appropriate materials should be used in outside design which included familiar environmental factors, in order to create an area which welcomes and absorbs children (Read, 2007). In other words, materials used in the garden should not only allow flexible physical movements but also encourage and inspire pupils to make projects and make up stories using their creativity (Caples, 1996). In this context, designs need to include playgrounds rich in materials where children and nature meet, where children's creativity is supported, where they will be able to do different activities (Duman\&Koçak, 2013). While designing these playgrounds, both arrangements should be done in a way which maximizes the personal development of each child, and facilities and resources should be integrated to make a balanced distribution of activities (Kalemci, 1998). Alamo (2004) emphasized that when designing playgrounds, physical playgrounds which include jumping, running and crawling; creative playgrounds which include sand, water, and lawn; sensory playgrounds in which children can use their visual, auditory and kinesthetic senses and silent playgrounds where students can rest and be alone should be included. As emphasized, designing playgrounds which foster development and creativity of children will increase educational quality (Başbay, 2012). In this sense, garden as outdoors should be designed as an educational environment as in central arrangements in classrooms and centers should be created where children can engage in activities in small groups (Kıliç, 2013). A model implementation was set forward in this research which will answer the questions concerning how outdoor center layouts can be; which centers can be created; what kind of materials can be used in these centers.

In research done, it was stated that outdoor playgrounds in kindergartens are insufficient in leading children to different games; are reorganized regardless of evaluating children's needs; and are too weak in terms of material (Çelik, 2012; Atabey, Yurt \&Ömeroğlu, 2009; Çevik, 2007; Oktayet al., 2006; Kalemci, 1998). 
Olgan and KahrimanÖztürk, noted that field arrangements where children can play different games are insufficient in the research they carried out in 34 different kindergartens. Başbay, (2012), stated in his research carried out in gardens of 45 government and private kindergartens that none of the playgrounds have creative centers and natural playgrounds are very few and inefficient. In his research done in 26 government and private schools, Kalburan (2012) emphasized the minority of natural playgrounds and deficiency of activity areas which support cognitive development. It was seen in all these research that especially literacy preparation and math activities are very few. However, even with water in a playground, children can have observation, estimation and evaluation experiences, and as a result of these experiences, they can acquire scientific processes. With acquiring these processes, children grow up as individuals who investigate, explore, criticize, solve problems and make decisions. For this reason, regulations should be made in a way children can have learning experiences using thinking skills (Büyüktaşkapu, 2013). Therefore, for these regulations to be made, people should develop an understanding and mentality regarding the importance of school gardens as outdoors in the development and learning experiences of children and how these learning environments can be designed (Kalburan, 2014). In this research, by putting forward a model implementation for preschool education institutions, it is aimed to contribute to the knowledge and perception. Thus, this research is expected to raise awareness and generate ideas concerning designing outdoors in preschools.

\section{Objective of the Research}

Learning centers are places where children can interact and learn by concentrating their attention, and should be should be organized in outdoors as well as indoors (Çelik\&Daşcan, 2014). In this regard, the objective of the research is to contribute to preschool educational institutions and teachers by propounding a model implementation. In accordance with this purpose, research questions are defined as follows;

1. What kind of centers can be created in the preschool garden as outdoors?

2. What are the opinions of teachers on centers constituted on the preschool garden?

\section{Method}

The explanatory case study was carried out which is a kind of qualitative research. An explanatory case study is about making the unknown known, correlate it with real life and explaining this correlation (Kaleli Y1lmaz, 2014). This research endeavors to make outdoor implication known and correlate it with education. In qualitative research, transmissibility rather than generalizability is more pronounced. To provide transmissibility, detailed depiction needs to be given to envision events and facts (Y1ldırım\&Şimşek, 2013). Within this framework, detailed descriptions of created outdoor centers were made. The instance is explained when depicted data are correlated within specific themes (Özdemir, 2010). In this context, 12 themes were constituted regarding children's zone of development, and in the end of a 2-month work, 12 centers (art, music, playing house, writing, balance, eye-hand coordination, vegetable, fruit, book, performance, sensory) were created. For the purpose of representing the effects of centers on children, interview method, which is a kind of 
qualitative research, was implemented and interviews with teachers on the effects of centers on children were analyzed descriptively.

\section{Participants}

The research was carried out in a research and application preschool of a university. Preschool teachers were interviewed to represent the impacts of 12 centers formed by the researcher on children. Criterion sampling was used in the research. For participants to be working in the school where the implication was done, be at least high school graduates, and be volunteers were determined as criteria. Participants are graduates from girl's vocational high school and have 2-5 years of professional seniority.

\section{Collection of Data}

To set forward a model outdoor implementation, design and center- forming study was done for 2 months. Centers constituted in the garden of the school were constructed with natural and waste materials found from the environment without any expenditure. With this aspect, centers prove to be a model which can easily be implemented to preschools. Free playgrounds were arranged along with centers. Park and garden workers provided service actively in the process of forming the centers. To make detailed depictions of the place, photographs of the preschool garden were taken after the outdoor arrangement is over. Views of the teachers upon outdoor use were collected with structured interview form. The interview form consists of 3 open-ended questions. These questions are generated concerning a) views on the effects of the application of centers to the education program; b) views on the effects of centers on children; c) views on the children's development of centers. Sub- themes of the data acquired from the interviews were analyzed with word repetition technique.

\section{Findings}

The findings gathered from the first question of the research "What kind of centers can be constituted on the preschool garden as outdoor?" was related to some information about the school and depiction of the centers created in the garden. After obtaining views of school administration and the teachers on what kind of centers can be constituted in the garden as outdoor, 12 centers were determined; and after the construction is over, photographs of these model centers were submitted as the depictions. The form concerning the dimensions such as physical structures of schools, activity types, zones of development generated by Chancellar (2013) and adapted to Turkish by Kalburan (2014) was examined and all of the concerns on the form were employed in the garden arrangement. Similarly, the checklist developed in the postgraduate thesis by Başbay (2012) was taken into consideration in the formation and arrangement of the centers, and arrangements of the centers were made precisely according to the entries in the list.

\section{Research and Application Preschool}

\section{The building}

The research and application preschool is affiliated to the Faculty of Education of Eskisehir Osmangazi University and offers service to institution employees. It is comprised of 7.583 
m2 field with 12 classrooms, 3 activity classrooms, a common playground, a dining hall, a storehouse and administrative area. The school has a big $5.101 \mathrm{~m} 2$ garden. The size of the garden ranges between $250 \mathrm{~m} 2$ and $500-100 \mathrm{~m} 2$ according to the needs of preschool children. (Aydin 2002). In terms of children's outdoor areas of usage, at least 6,5 $\mathrm{m} 2$ field should be allotted per child in preschool education institutions (Ömeroğlu, 2004). With this regard, the size of the preschool assigned for the implication was deemed suitable.

\section{Education}

Tenured teachers of the Ministry of National Education are employed in the preschool in compliance with the protocol signed between the preschool and Eskisehir Provincial Directorate of National Education. Ministry of National Education Preschool EducationProgram is implemented qua education program. The institution provides service between $8.00-17.00$ hours with priority for the children of personnel.

\section{Capacity}

The preschool has maximum 185 children capacity and this number varies depending on the enrollment demands. A teacher, an assistant teacher and a support staff render service in each classroom. Within this framework, 12 teachers, 14 assistant teachers, 11 support stuff, 4 clerks, a principal and a coordinator serves in the school.

\section{Garden}

Preschool gardens provide opportunities for children to play kinetic games such as running, jumping, and playing ball. For this reason, wide outdoor areas should be created to enable activities (Uysal, 2006). The garden of the preschool provided many advantages in terms of design as it is quite spacious, exactly 5.101 square meters. School garden's arrangement and care service are delivered by the Directorate of Gardens and Parks of the university. What kind of centers (art, music, playing house, writing, balance, eye-hand coordination, vegetable, fruit, book, performance, sensory) can be created in the garden where the outdoor regulation was carried out was determined by the school administration and teachers. The places of the centers identified for children with visual sign boards. Every morning before the classes start, materials such as chalk or paint used in centers, kept in transparent storage boxes are carried to their centers and after the classes finished, these boxes are carried back to the storage. Depictions of the centers are made according to the fixed materials they include.

\section{Art center}

Children can work more freely with bigger drawing papers and other art supplies without hesitation or apprehension to spill or splash (Henniger, 1999). In is context, an art center was designed to promote children's development. There are 3 knights in the art center and beside them there are 3 logs where children can put their art supplies. The art center is distant from other centers and close to the vegetable and fruit centers. A big spool used in building constructions was placed in the center for children to put their art supplies. 


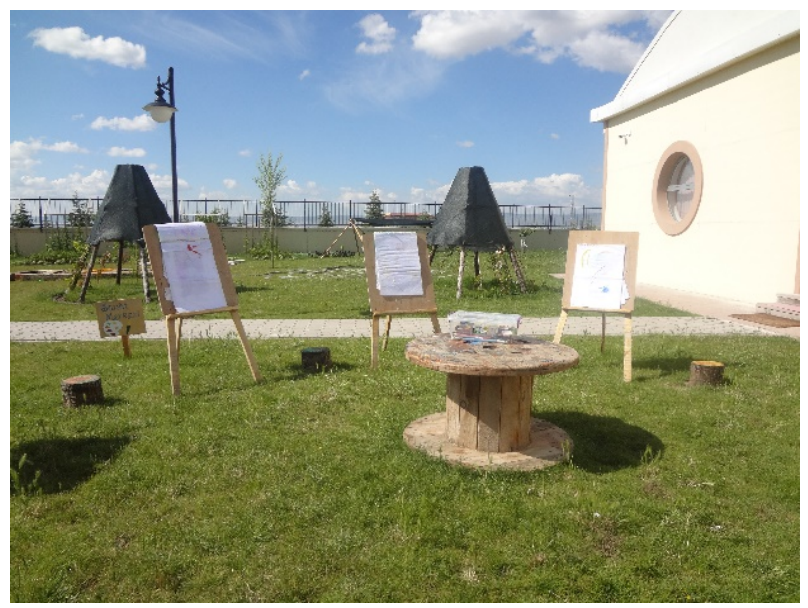

Figure 1. Art center

\section{Vegetable center}

Kalemci (1998) concluded his research that there was very little space in preschool gardens allotted for planting. Natural elements such as trees, plants, rocks, pebbles, water which are used in playgrounds are primary elements which will afford children assistance to learn about universe and nature, to gain fundamental experiences, and to help them become creative and productive individuals. For this reason, designs should include natural elements, especially plants; and lawns and flowers should be used when creating playgrounds. (Çukur, 2011; White \&Stoecklin, 1997). After greening the field where the implication will take place, the each classroom was allotted a portion from the garden for children to experience planting; and tomato, pepper, eggplant, bean, cucumber and strawberry seedlings were planted with children. Pepper weed, parsley, and lettuce seed were planted into crates. At the base of the cloture, ivy plants were planted and beneath them hammocks were assembled. Hangers were assembled on the walls so that children can hang their watering containers. Drip irrigation system was installed to the vegetable center taking holidays and weekends into consideration.
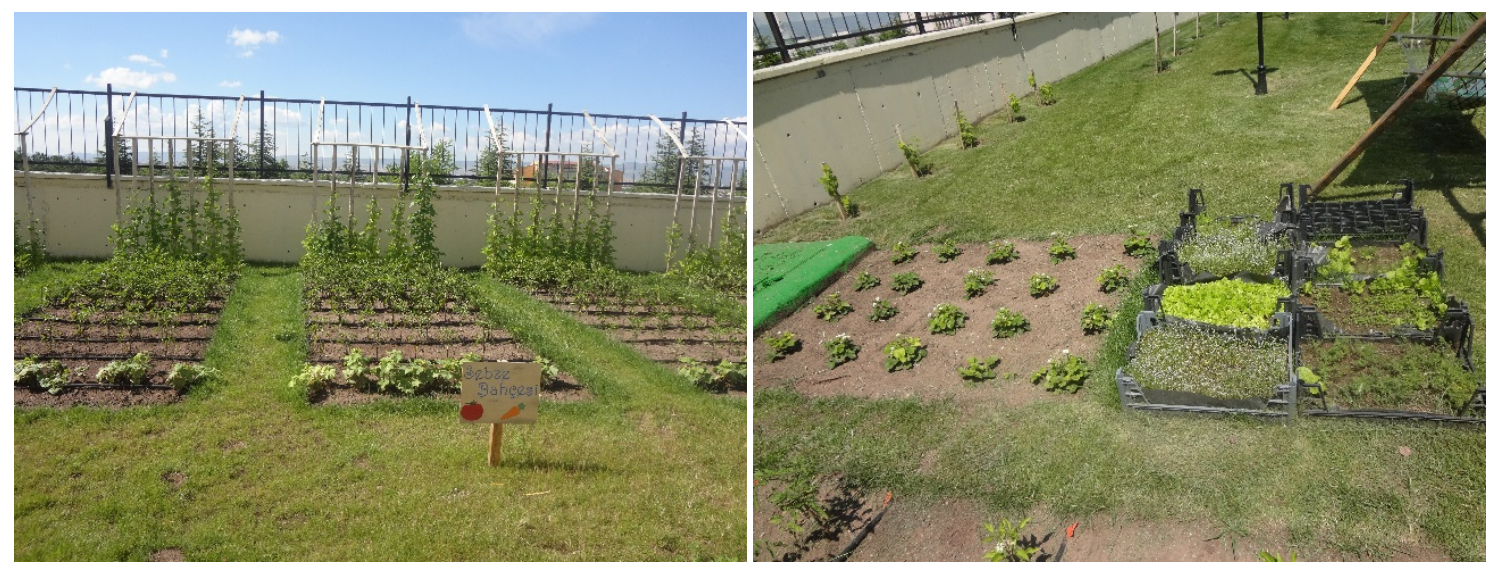

Figure 2. Vegetable center 


\section{Macrothink}

\section{Fruit center}

In preschool education institutions' gardens, plantation fields should be created wherever possible. This kind of implementations broaden classroom activities in a significantly (Caples, 1996). To develop children's planting skills, besides the vegetable center, a field was planned to be devoted for fruit trees. Next to the vegetable center, 2 cherry trees, 6 pear trees, 6 apple trees, 4 apricot trees, 2 walnut trees, 2 white mulberry trees, 2 plum trees and 2 medlar trees were planted with children in the fruit center. Marking tags were created for each tree and were tied to the branches of the trees.
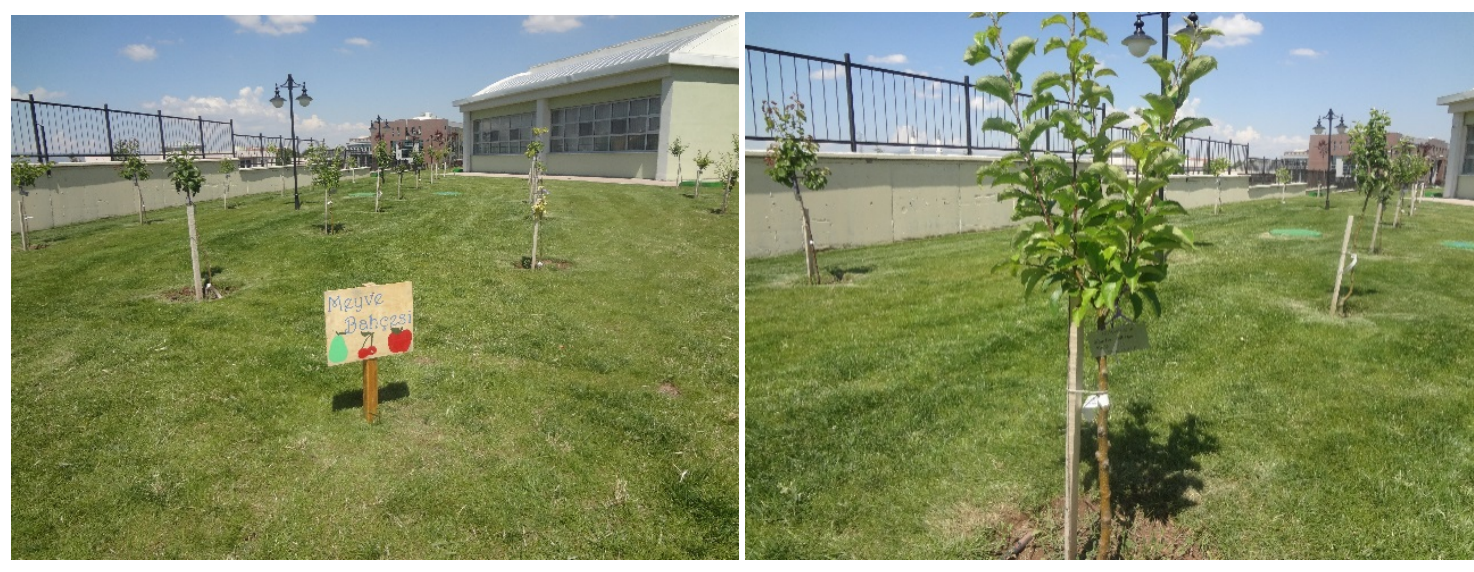

Figure 3. Fruit center

\section{Sensory center}

With the intention of providing children sensory experiences with different kinds of materials, five compartments were constructed out of waste thick timber previously used in railways. A basin was put in the 3rd compartment to put water in it. The first compartment was filled with sand; the second compartment was filled with pebbles; the third compartment was filled with water; the fourth compartment was filled with spinning wood pieces; and the last compartment was filled with smoother materials such as leaves, stalks, and weeds. The materials used can be changed by the teacher's arrangements. Children walk on these compartments with bare feet by the supervision of the teacher and are asked questions about their senses. 


\section{Macrothink}
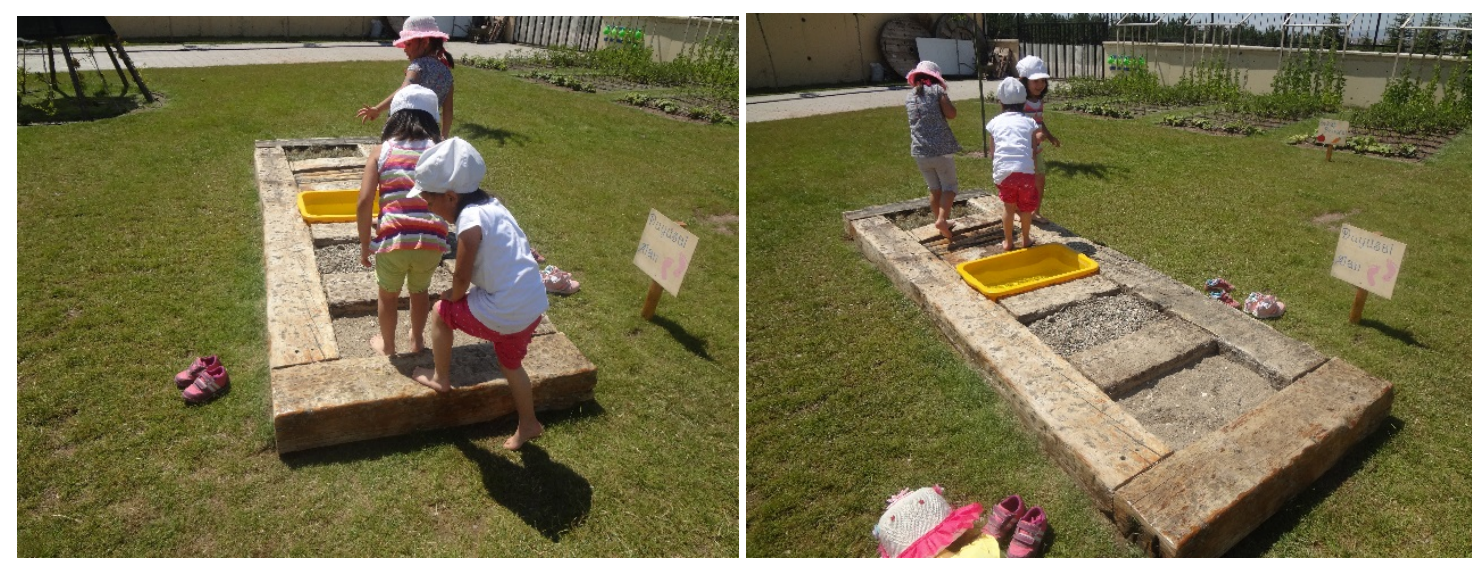

Figure 4. Sensory center

\section{Book center}

Reading stories in outdoors under a tree or other proper places are more efficient and foster the feeling of freedom in children (Henniger, 1999). The book reading center was created to promote the interest on reading books and to establish more effective reading activities. Seven big timber slices were anchored to the ground in a round shape so that 6 students and a teacher can sit. An old construction spool was put in the middle of the center to use as a table. The books of the center are carried to the center every morning in a container.

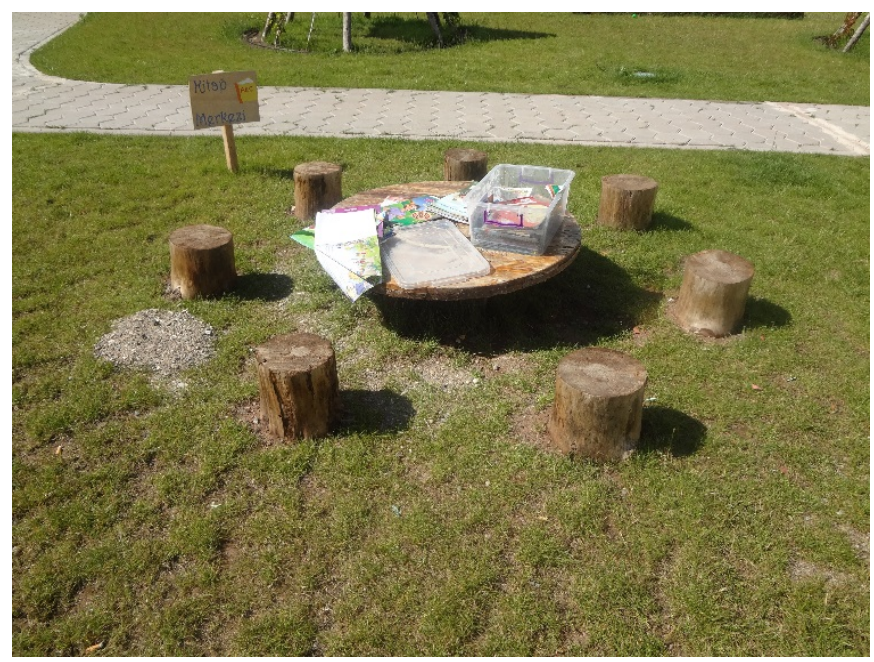

Figure 5. Book center

\section{Drama center}

Drama center was thought as a small theater stage where students can act different roles and characters with various materials and costumes they bring from their classrooms. Thick timber planks formerly used in railways were encountered in the warehouse of the university and were brought to the garden of the preschool. The center was designed as a place where children can sit on the imbricated timber. 


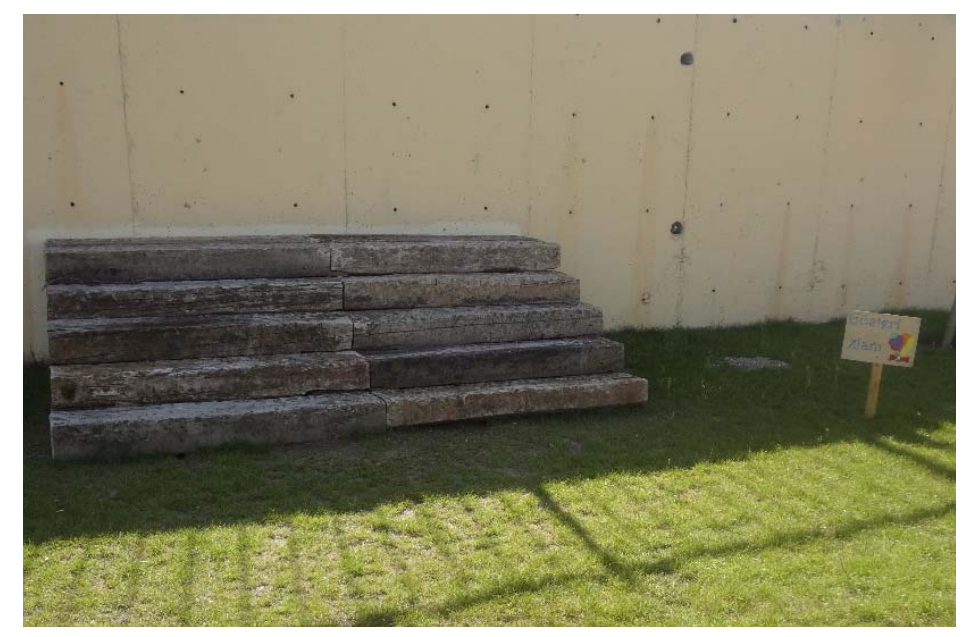

Figure 6. Drama center

\section{Playing house center}

Playing house center which provides a house setting was created so that children understand the properties of domestic life by getting in different roles. A countertop was formed out of wood beside the playing house which already exists. Holes were created on the countertop and plastic basins were put in the holes to imitate sinks. Above that sinks plastic bins with faucets were situated so that children can use water on these sinks. Kitchen tools were provided from families so that children can use in the center. An old construction spool was situated amidst the center for children to use as a table. Little stools were formed out of wood so that children can sit.
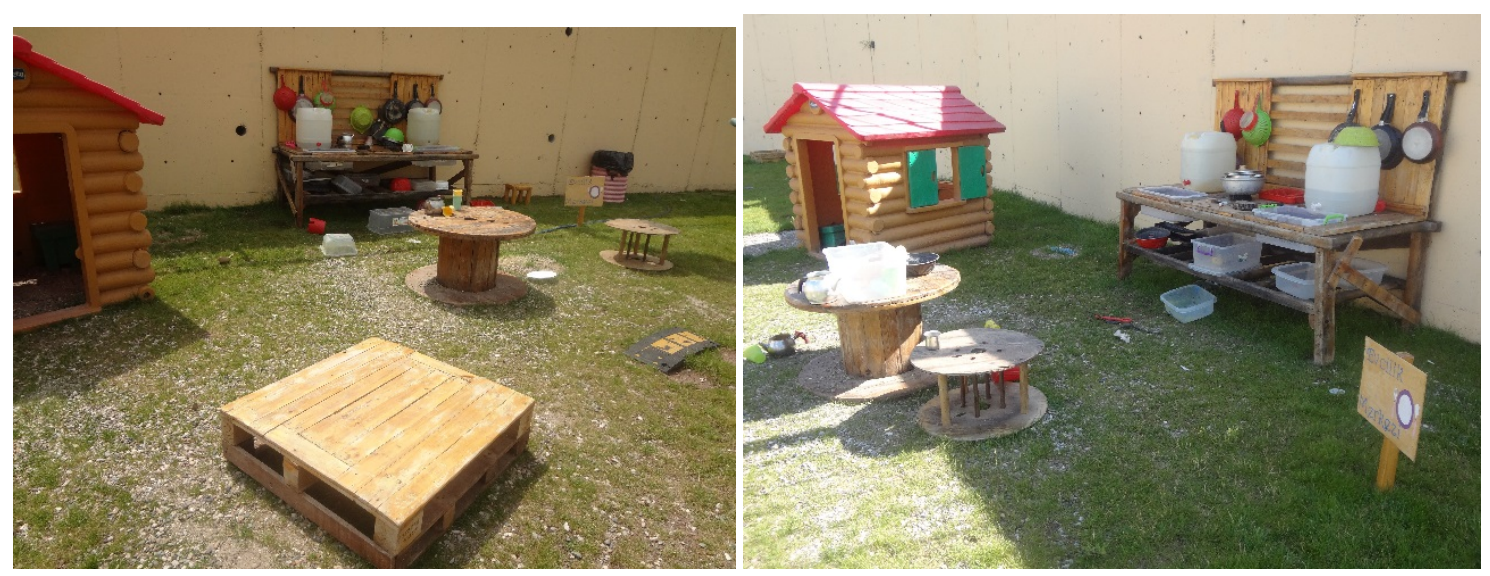

Figure 7. Playing house center

\section{Hand-eye coordination center}

With the aim of providing children an opportunity to develop their hand-eye coordination, a center was formed where they can shoot balls. This center, which requires children to throw or shoot the small balls in the desired direction, has two parts. The first part has 4 interwoven hoops. 5, 10, 15, and 20 numbers were cut out of wood and fixed on the ground in the hoops. Children are expected to shoot the highest number. In the second part of the center, children 


\section{Macrothink}

Journal of Studies in Education

ISSN 2162-6952 2016, Vol. 6, No. 1

are expected to throw the balls in the boxes in various sizes. A wood which is in the upside down u shape was fixed on the ground; equally spaced tin cans which have $5,10,15,20$ numbers on them were hanged from the wood. The can which has number 20 on it is the smallest one in size and the can which has number 5 is the biggest. Children are expected throw the ping pong ball in the smallest can and get the highest score. A small wooden box was carved out of wood to put the balls in it. There is also an upside down V shape timber which has 5 plastic hoops attached in it. Big balls which children throw through the hoops were put inside a big box.
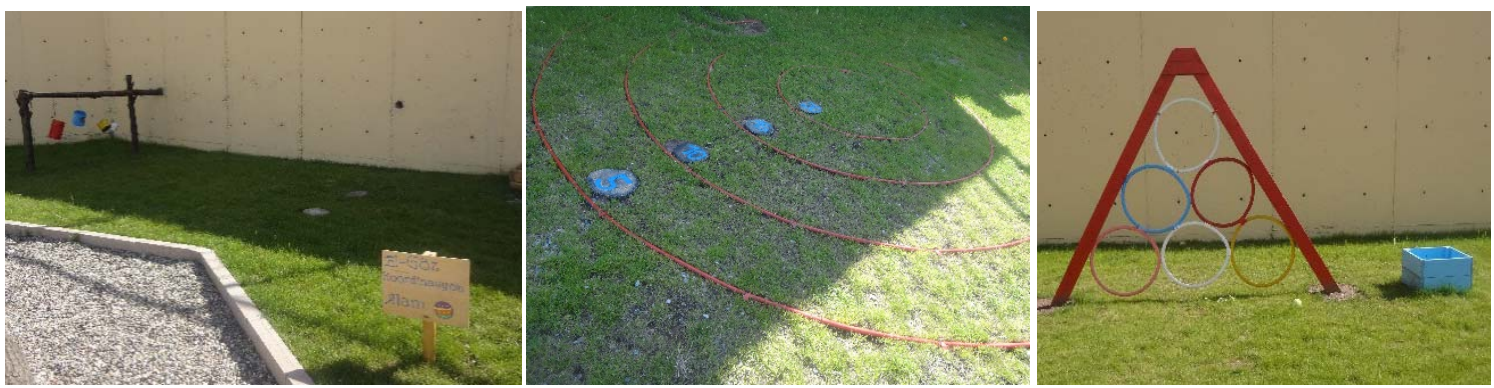

Figure 8. Hand-eye coordinationcenter

\section{Music center}

Doing activities such as singing, dancing and creative physical activities in the outdoorsboost relaxation and peace of children (Henniger, 1999). A music center was created where children can do soothing musical activities outdoors. A big drum made of tin cans and a xylophone was situated in the center where children can develop sound awareness and practice rhythm work. An arrangement was made with jar lids with which children can produce different sounds. Aluminum kitchen plates in different sizes were mantled on the back surface of the xylophone.
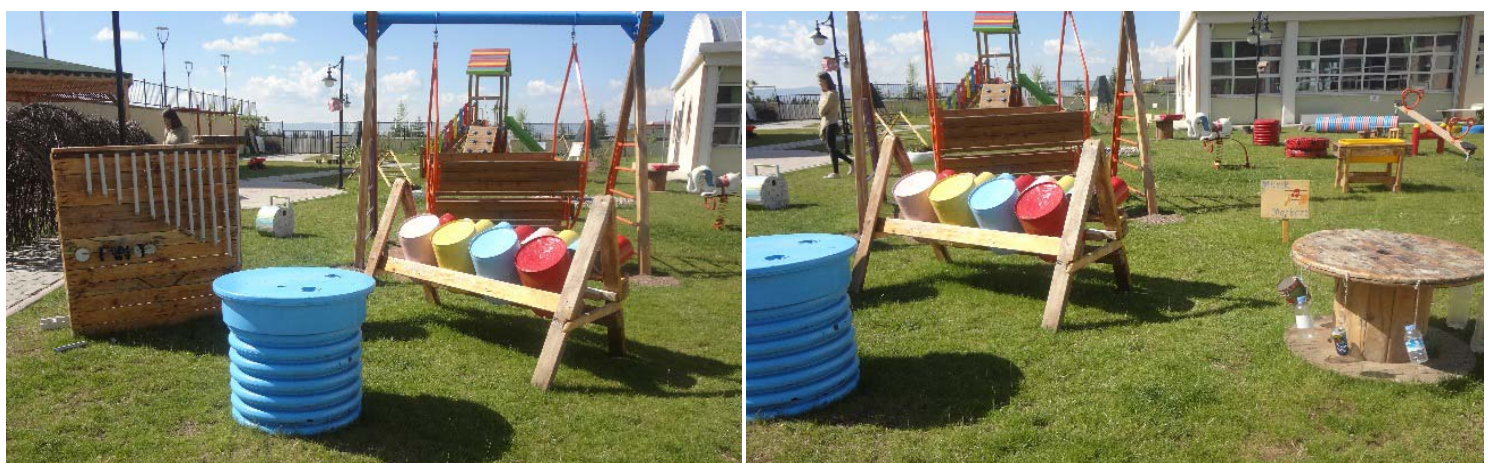

Figure 9. Music center

\section{Writing center}

Within the context of preparation to writing development, the writing center was formed to enable children for drawing and painting. With this regard, 2 timber pieces were fixed on the floor and a blackboard was put on the timber horizontally as a table where children will be able to develop figure- ground perception, position in space, hand- eye coordination, holding 


\section{Macrothink}

Journal of Studies in Education

ISSN 2162-6952 2016, Vol. 6, No. 1

a pen and using finger skills. Also, stand chalkboards in various colors were put in the center. Every morning, chalks, pens, and papers are brought to the center.

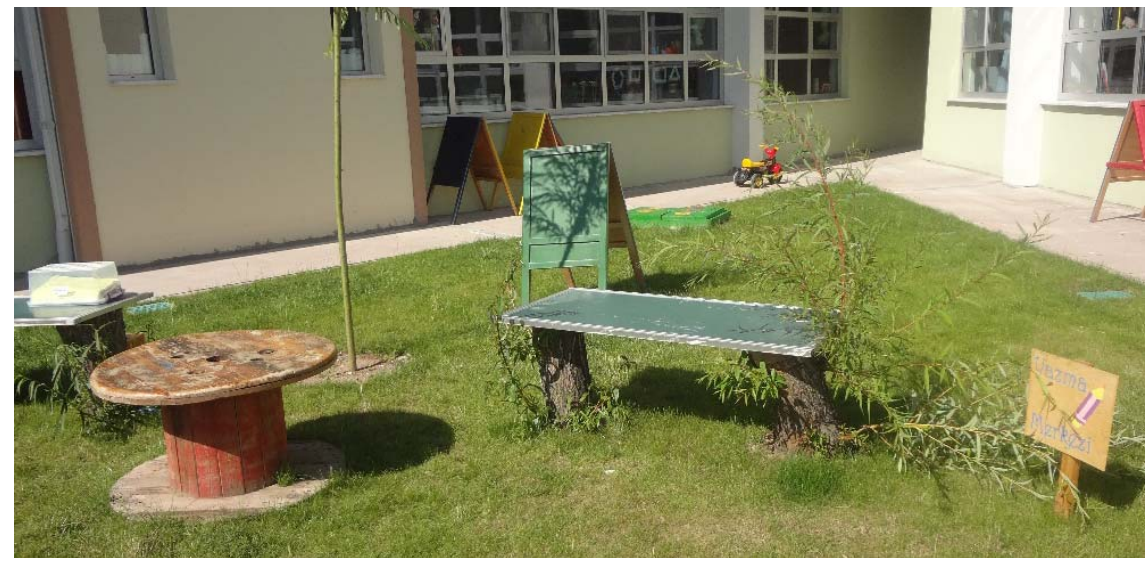

Figure 10. Writing center

\section{Science center}

A science center was planned where children will be able to realize science and math activities and where their cognitive development is fostered. In the science center, a wood attached to a spool was made which is used as a scale. A ball throwing mechanism was designed on a wooden block which enables children to experience gradient, direction and distance. Behind this mechanism, a water duct was designed using funnels and hose in different thickness where children can experience the concepts such as volume, few- many, big- small, thin thick and so on. Every morning tools such as magnifying glasses, magnets, and insect observing containers are carried to the center.
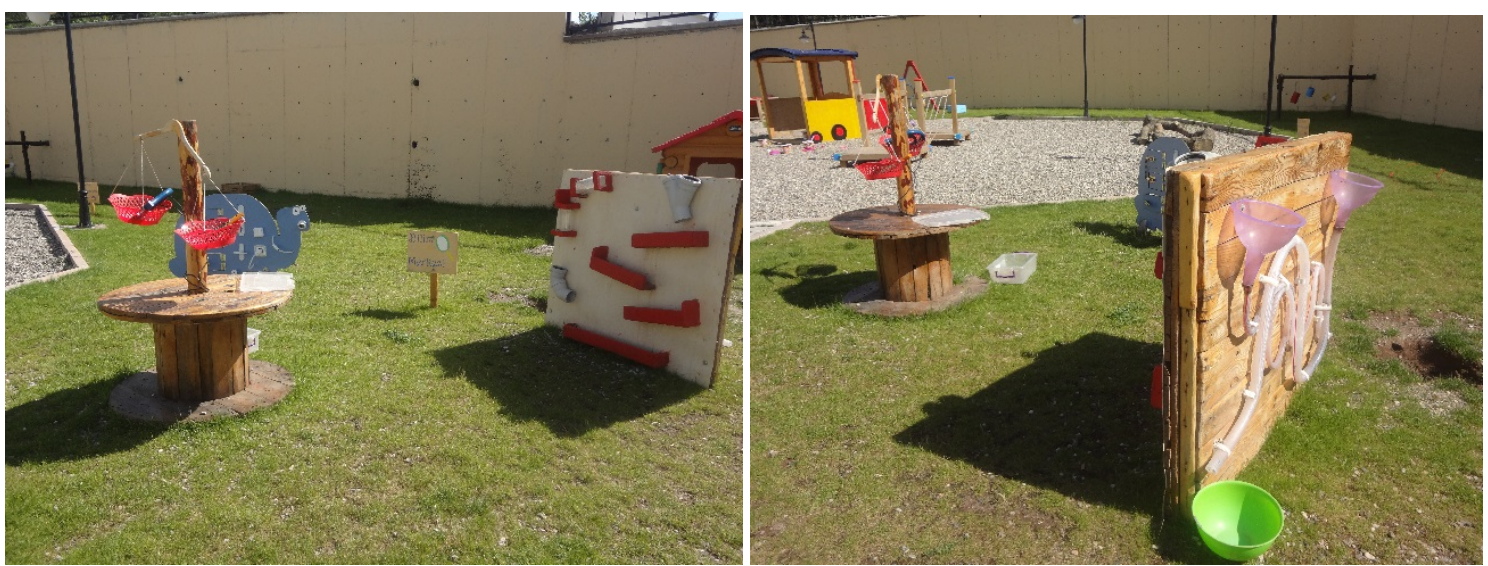

Figure 11. Science center

\section{Balance center}

Playgrounds in the gardens are the bridges between the world and imagination and are places where variable ground levels, falling and standing are abundant (Caples, 1996). Two bulges were connected by a wood piece to imitate a balance board where children will try to walk in 


\section{Macrothink}

Journal of Studies in Education

ISSN 2162-6952 2016, Vol. 6, No. 1

balance; and an arrangement was made consisting of tires in various shapes for children to walk on. Also, another arrangement was designed in the center which consists of nested car tires. The activities which will be done in balance center will support the physical development of children.
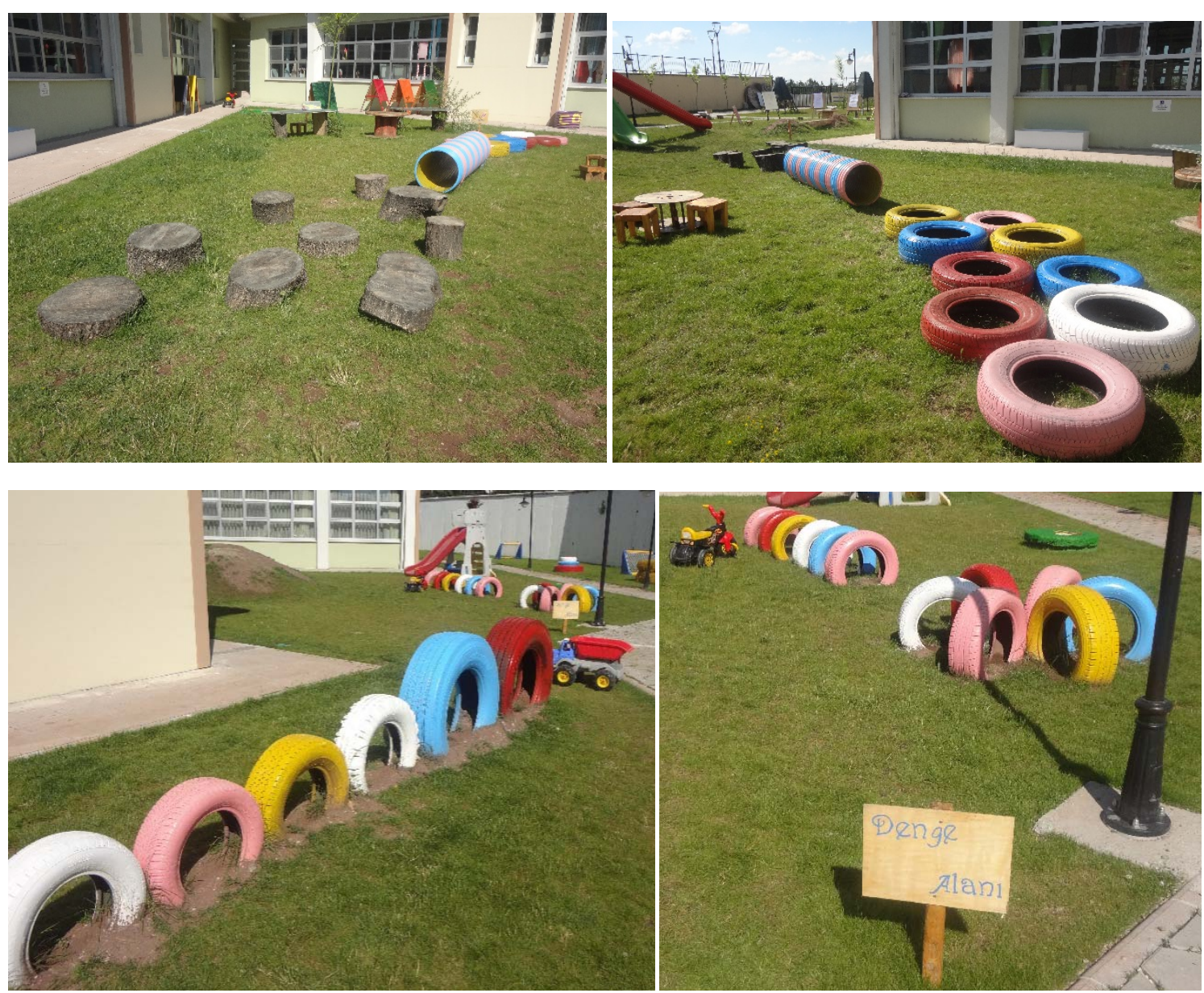

Figure 12. Balance center

Providing opportunities to run, jump, climb fosters children's physical development (Uysal, 2006). Hence; slides, dander boards, swings, scaling ladders, hammocks, sand pools which are supporters of children's physical skill development should be included to outdoor designs (Acer, 2007). Also, the bumps are ideal for running and jumping and are also a natural shelter for passive games such as sand and water games. The bumps should be small and should be placed behind or beside the playgrounds (Decker \& Decker, 2003). In this framework; swings, slides, dander boards, sand and water pools, a pebble playground, hay bundle playground, tunnels, paths, an arbor as a garden class, sensory tables, a garden pool made from tractor tire, a plane made from hose was installed apart from the centers for children to play actively or passively to support their development. 


\section{I Macrothink}
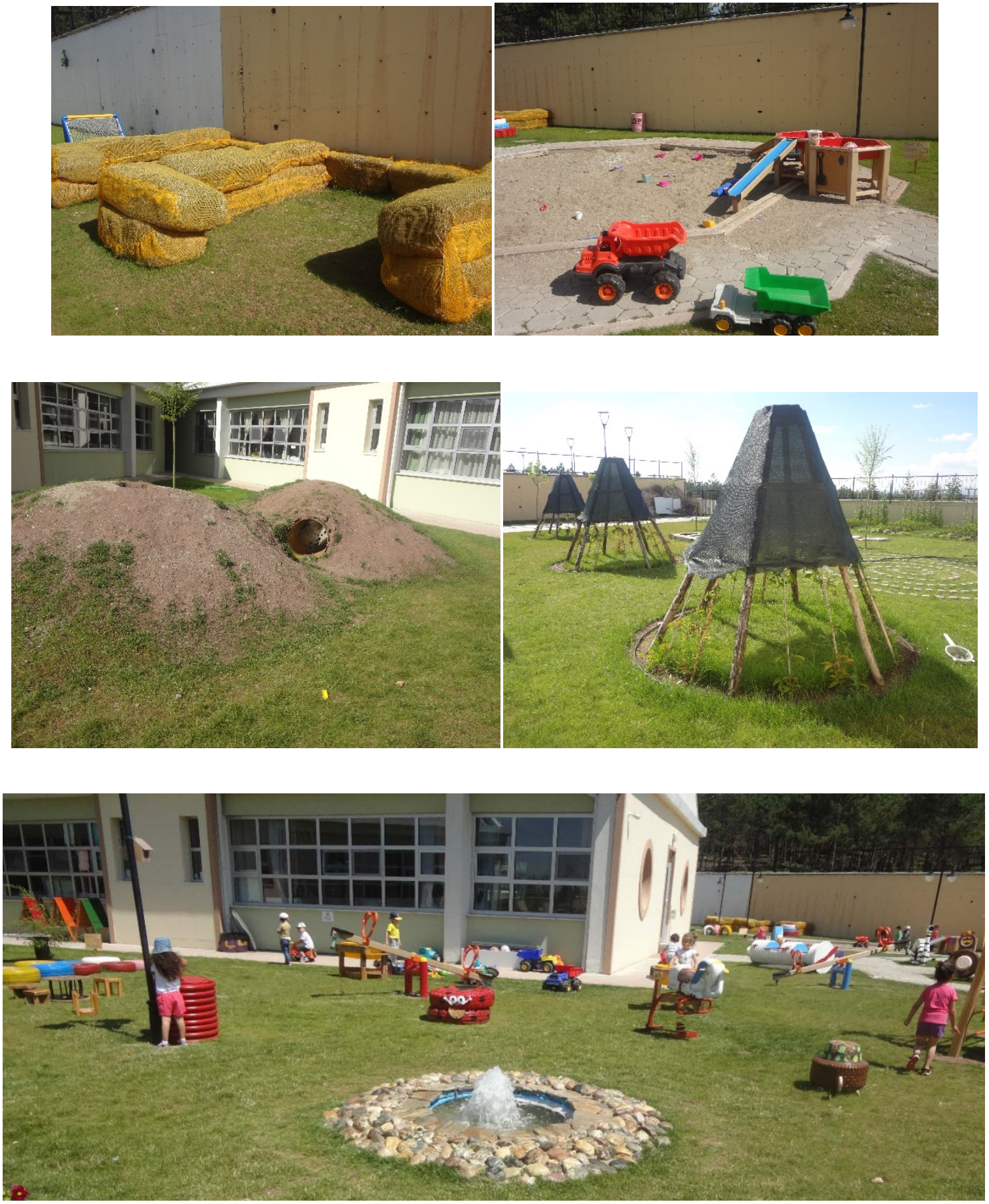

Figure 13. Playing center

Findings on the second question of the research "What are the views of teachers on the centers created in the garden of the preschool?" were analyzed with word repetition technique and presented below with teacher's statements.

The opinions of the six teachers who worked in the kindergarten where the practical application was made were taken under three questions. Teachers responded to the question "What are the benefits of the centers (art, music, house games, science, writing, balance, hand-eye coordination, vegetables, fruit, books, shows, sensory) created in the school garden 
on the education program?" was evaluated according to the obtained sub-themes are given below.

- A wide range of applications

- $\quad$ Learning by doing andliving

- Creativity

- Productivity

Thanks to centers created in the garden, teachers say that children have wider application areas not only to staying connected to the classrooms, their learnings are supported by doing and by living, creative activities are applied and because of that efficient application occurs. The statements of some of the teachers are as follows.

T1: "I think, these centers provide big opportunities for children. In my opinion, they are doing a lot of things by conscious effort. Thanks to these centers in the garden, these centers attract more attention; they concentrate on the centers. We can also do better observation. I think children communicate with us more. They ask questions like "How can we play here? Or "What else can we do?" This interest helps to plan more attractive and absorbing activities. I am observing that when children came to the school they always want to go out to the garden. In showcase center, showing owing ideas, in art center making paint in nature, in music center composing songs with bird chirps, in balance and hand-eye coordination center motor development provide us both wide application area and efficient education application. In our school garden, each center aims acquisition of various skills. We are having plenty of time with children and supporting their acquisitions."

T3: "Our education areas are not limited only with classes; we have a wider environment where various possibilities exist. Children are learning lots of things by doing, by experiencing on their own. The efficiency of the activities is increased. We can plan more creative activities thanks to increased number of materials and the expansion of the area."

Answers to the other question "What are the effects of the centers which were created in the school garden on the children?" was evaluated, and following themes were reached.

- New areas of interest

- Creativity

It was stated that children improved new areas of interest for nature and improved their creativities doing different things. Some teachers stated followings.

T5: "Children love with playing with sand and mud; with their imagination, cakes and meals. In the music center, they are learning to obtain different sounds from different instruments by exploring. Especially they have more attention to the emotional area, and soforth. Thanks to the centers, they are starting to develop interest and wonder on different things. With my observations, I can see they can think and approve different things." 
T6: "They turn different centers which are not placed in our class. Thanks totheircreativity and free expression areas for children, areas of interests of children improved. They can be more creativity by nature."

When the answers to given last questions "What do you think about the effects of outdoor centers on the children?" was evaluated, following sub-themes came out.

- $\quad$ Thinking abilities

- Creativity

Teachers stated that playing in outdoor centers have effects on children such as improving questioning, choosing, making decision and problem solving. It seems that besides sub-themes, teachersalso stated that, supported all areas of children is an important finding. Some teachers' opinions are below:

T1: “Actually it affects lots of thing on our children. Especially playgrounds which are supportive to big muscle progress are so effective. It supports children's progress very well. Our children step up on the wheels, jump over the wheels, slip through the wheels, go into tunnels, climb and stand in balance. I think children gain success as they can. It is a good fortune that is not found somewhere else. The sensorial space that is our children's favorite and which is found in our garden provides them progress. It is a great opportunity that stepping on stone, land, wheat steam, sand and water by pulling off socks and observing what they feel when they step on these materials, then asking, learning their thoughts and letting them think. I truly think there is an effect which aims and supports the acquisition on children and cheering up the children and making them happy. The children are constantly thinking and producing new things thanks to the centers."

T3: "Children have obtained information by going beyond the theoretical information and experiencing with observation and practice. Their physical development is being supported by various materials that are designed to support major and minor muscle group abilities. In general, the centers are expanding their imagination by letting them use their imagination freely. They can imagine and create many different things. I listen to them talking to each other sometimes. I realize how much they have been mentally developed."

T2: "I think they have had a mental development, improved their emotions and opinions, shown their creative ways, gained self-esteem and socialized also their physical development was provided."

Considering the views of the teachers, it has seen that dividing the kindergarten yard into centers to support the development areas such as classrooms, has positive results towards the effect on children and the support on their development.

\section{Conclusion and Discussion}

In a research where the arrangement of school garden as outdoor, as in the arrangement of centers in classrooms in accordance with pre-school teaching program was set as an modelimplication, the following questions have been asked, "How can centers be arranged in 
kindergarten gardens as outdoor?" and "What are the views of the teachers on the centers createdin the kindergartengarden?". 12 center centers (art, music, playing house, science, writing, balance, hand-eye coordination, vegetable, fruit, book, drama, sensorial) were been set by preliminary interviews of teachers on how to form centers intended for the need and interest of the children and by examining the control lists used for studies to demonstrate the suitability of school garden. It was designed by the researcher to have minimal cost by using natural and waste material and built by the researcher ready to use in two months. Teachers' opinions were received after using centers as the educational environment for two months.

According to the interviews with teachers, learning by practicing, experiencing, creativity, productivity, new fields of interest, shaping thinking skills and themes of creativity and expressing their opinions positively are evaluated that it can be an implementation for the scientific process.

In the interviews, teachers have stated that the applying the implementation to the school garden that pre-school programming provides the center in class makes students more willing to go to the garden gives a chance to develop their growing and enable to apply the curriculum all-around thanks to the head office. Besides spendingmore time effectively and playingfreer games and activities by the supervision ofteacher, they can organize both big and small group activities according to teachers' statements.

When teachers' views were evaluated, changing into the garden that is provided by the using effectively and actively is seen. Providing these changes outdoor has a great importance for the development of the children. Pre-school children need playing field that meets their evolving motor ability, developing cognitive skills and peer communications. Children can run, jump and join in so many playing activities in the playing fields of outdoor. The factors of challenging and risking in those games give an explanation why children prefer these places more. Another advantage is that objects that are seen, heard and touched affect all senses. Therefore, children choose an outdoor for playing. For children that can be more active and more free outdoor, relations that they give attention and interact with each other should be done. In these fields, they can discover their ability and create their own games. To provide children's development ultimately, we need to put in order pre-school gardens, which in respect to the material. Durmuşoğlu(2008) have taken 180 teachers' opinions about education environment and have revealed that teachers indicate that are inadequate in terms of regulation and material although they think the size of the garden is partially enough. Answers are tried to find about how these presented inadequacies would be resolved and what would be done with the model implication.

In the example of the practice that presented in the search, it was tried to build centers and practice was evaluated with meetings. To the extent permitted by kindergarten that is determined as guide model, taking into consideration the interests and needs of children, it is constituted with using products obtained from construct and natural materials without spending. For sure more different and more enriched contented practice can be done. This survey, as an example, gives an idea to the educators about how changes might be done and about how to use center practice. Design that will support children' in multiple developments, 
should be created by pre-school institutions and teachers; and garden as an outdoor should be activated. It is thought that this survey which was done in this sense will make a difference in educational institutions.

\section{Limitations of the Research}

This survey has two important restrictions. One of them is that the modelimplementation was carried out inonly one kindergarten. The other important restriction is that only six teachers' opinions were received on a volunteer basis. In this regard, the application is suggested to be performed in more kindergarten gardens with more different designs and opinions are suggested to be received from more teachers. In addition, observations of children are needed to be increased.

\section{References}

Acer, D. (2007). Okul öncesi ĕgitim kurumlarının fiziksel ve eğitsel ortamları. Okul Öncesi Eğitime Giriş. G. Haktanır (Ed:). Ankara: Anı.

Alamo, M. R. (2004). Design for fun: Playgrounds. Structure: Barcelona.

Atabey, D., Yurt. Ö., \& Ömeroğlu, E. (2009). Okul öncesi eğitim kurumları açık hava oyun alanlarının incelenmesi. Uluslararası 5. Balkan Eğitim ve Bilim Kongresi, Edirne.

Aydın, Ç. N. (2002). Bahçe oyunları özen ister.Çoluk Çocuk, 14, 10-11.

Başbay, A. M. (2012). Ankara ili sınırları içindeki özel ve resmi anasınıfi ve anaokulu bahçelerinin kullanım yönünden incelenmesi.Yüksek Lisans Tezi, Hacettepe Üniversitesi, Sosyal Bilimler Enstitüsü, Ankara.

Büyüktaşkapu, S., \& Akman, B. (2013). Bilimsel süreç becerileri. Okul öncesi dönemde fen eğitimi.Uyanık- Balat G., Güler T. (Ed). Ankara:Pegem Akademi

Caples, S.E. (1996). Some guidelines for preschool design. Young Children, 51(4), 14-20.

Çelik, A. (2012). Okul öncesi eğitim kurumlarında açık alan kullanımı: Kocaeli örneği. Atatürk Üniversitesi Ziraat Fakültesi Dergisi, 43(1), 79-88.

Çelik, N., \& Daşcan, Ö. (2014). Son değişikliklerle okul öncesi ĕgitim programı ve etkinlik kitabl. Ankara: Anı.

Çukur, D. (2011). Okulöncesi çocukluk döneminde sağlıklı gelişimi destekleyici dış mekan tasarımı. Turkish Journal of Forestry, Türkiye Ormancılık Dergisi, 12(1), 70-76.

Decker, C.A., \& Decker, J.R. (2005). Planning administering early childhood programs.NJ:Merril Prentice

Dere Çiftçi, H., \& Aksoy, A. B. (2014). Erken çocukluk döneminde oyun. Ankara: Pegem.

Duman, G., \& Koçak, N. (2013). Çocuk oyun alanlarının biçimsel özellikleri açısından değerlendirilmesi (Konya ili örneği). Türk Ĕ̆itim Bilimleri Dergisi, 11(1), 64-81. 
Durmuşoğlu, M. C. (2008). An examination of the opinions of preschool teachers about preschool learning settings in their schools. Eurasian Journal of Educational Research, 32, $39-54$.

Henniger, M. L. (1999). Teaching young children.Upper Saddle River, NJ: Prentice-Hall

Jalongo, R.M., \& Isenberg, P.J. (2000). Exploring your role in designing a safe, healthy, and appropriate early chlldhood environment. Exploring Your Role a Practitioner's Introduction to Early Childhood Education. NJ: Prentice Hall.

Kalburan, N. C. (2014). Denizli ilinde bulunan resmi ve özel anaokulu bahçelerinin karşılaştırmalı olarak incelenmesi.Pamukkale UniversityJournal of SocialSciencesInstitute/Pamukkale Üniversitesi Sosyal Bilimler Enstitüsü Dergisi, 18, 99-113.

Kaleli Yılmaz, G. (2014). Durum çalışması. Kuramdan uygulamaya eğitimde bilimsel araştırma yöntemleri.Metin, M. (Ed.). Ankara:Pegem.

Kalemci, F. (1998). Okul öncesi eğitim kurumlarının çevre düzenlemesi ve çalışan eğitimci personelin nitelikleri yönünden incelenmesi. Ankara: Aydoğdu Ofset.

Kılıç, Z. (2013). Anasınıfina devam eden çocukların okul bahçesinde görmek istedikleri ortam özelliklerinin belirlenmesi.Yüksek Lisans Tezi, Ankara Üniversitesi, Eğitim Bilimleri Enstitüsü, Ankara.

Olgan, R., \& Öztürk, D. K. (2011). An investigation in the playgrounds of public and private preschools in Ankara. Ĕgitim ve Bilim, 36(161), 85.

Özdemir, M. (2010). Nitel veri analizi: Sosyal bilimlerde yöntembilim sorunsalı üzerine bir çalışma. Eskişehir Osmangazi Üniversitesi Sosyal Bilimler Dergisi, 11(1), 323-343.

Read, M. A. (2007). Sense of place in child care environments. Early Childhood Education Journal, 34(6), 387-392.Doi: http://dx.doi.org/10.1007/s10643-006-0148-1

Richardson, G. R. (2006). Creating a space to grow developing your outdoor learning environment. London: David Fulton Publishers.

Uysal, F. (2006). Okul öncesi eğitim merkezlerinde iç ve dış mekan organizasyonlarının eğitim yaklaşımları çerçevesinde incelenmesi. Yayımlanmamış Yüksek Lisans Tezi, Gazi Üniversitesi, Fen Bilimleri Enstitüsü, Ankara.

Yıldırım, A., \& Şimşek, H. (2013). Sosyal Bilimlerde Nitel Araştırma Yöntemleri. (9. Bask1). Ankara: Seçkin Yayıncılık.

Yazıc1, Z.,Yellice, B., \& Özer, D. (2003). Okul öncesi ĕgitim ortamlarının dĕgerlendirilmesi üzerine bir inceleme. Türkiye okul öncesi eğitimi geliştirme derneği OMEP dünya konsey toplantısı ve konferansı bildiri kitabı. G, Haktanır ve T. Güler (Ed.). Kuşadası.

Wellhousen. K., \& Crowdher, I. (2004). Creating effective learning environments. Canada: Thomson Learning. 